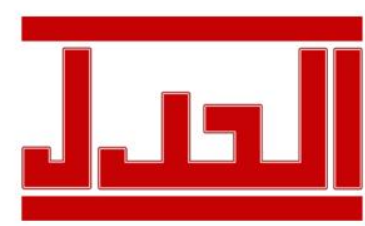

ISSN: $1979-4940$

E-ISSN: 2477-0124
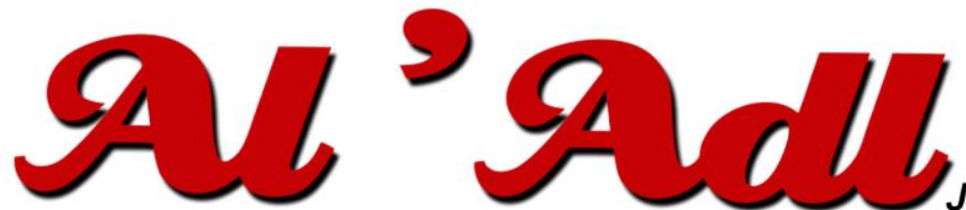

Jurnal Hukum

Editorial Office: Faculty of Law, Islamic University Of Kalimantan,

Jalan Adhyaksa No. 2 Kayutangi Banjarmasin, Kalimantan Selatan, Indonesia (70123)

Email: al_adl@uniska-bjm.ac.id

Web: http://ojs.uniska-bjm.ac.id

\title{
TUGAS DAN FUNGSI KEPOLISIAN DALAM PERANNYA SEBAGAI PENEGAK HUKUM MENURUT UNDANG- UNDANG NOMOR 2 TAHUN 2002 TENTANG KEPOLISIAN
}

\author{
Muhammad Arif \\ Universitas Islam Kalimantan \\ Jl. Adhyaksa Nomor 2 Kayutangi Kota Banjarmasin 70123 \\ Email: m.arief.sh.mh.ma@gmail.com
}

\begin{abstract}
Submitted
: 11 Januari 2021

Revised

: 25 Januri 2021

Accepted

: 29 Januari 2021

Published

: 31 Januari 2021
\end{abstract}

\begin{abstract}
The purpose of this research is to find out how the duties and functions of the police in their role as law enforcers according to Law No. 2 of 2002 on Polri. As well as knowing what factors hinder the role and function of the police in carrying out their duties. The method used in this research is the normative method. The results of the study concluded that in state life there are various regulations that force people to obey and obey the applicable rules. The nature of submission and obedience to regulations is due to legal awareness, namely understanding the meaning and purpose of law for masses. POLRI as law enforcement agent and guardian of security and public order. The conception of the duties, functions and roles of the National Police originates from a foundation that is still relevant but still needs to be integrated with community development. The duty of the police is to maintain security and public order, enforce the law and provide protection, protection and services to the community to realize the wishes in law to become an obligation and be obeyed by the community
\end{abstract}

Keywords : The Duties and Functions, Role As Law;

\section{Abstrak}

Tujuan dari penelitian ini adalah untuk mengetahui bagaimanakah tugas dan fungsi Kepolisian dalam perannya sebagai penegak hukum menurut UU No. 2 Tahun 2002 tentang Polri. Serta mengetahui faktor-faktor apakah yang menghambat peran dan fungsi kepolisian dalam melaksanakan tugasnya. Metode yang digunakan dalam penelitian ini adalah metode normatif. Hasil penelitian disimpulkan bahwa dalam kehidupan bernegara terdapat berbagai peraturan yang memaksa masyarakat untuk tunduk dan patuh pada aturan yang berlaku. Sifat ketundukan maupun kepatuhan terhadap peraturan karena adanya kesadaran hukum, yaitu memahami makna dan tujuan hukum bagi kemashlatan. POLRI sebagai agen penegak hukum dan pembina keamanan dan ketertiban masyarakat. Konsepsi tugas, fungsi dan peran Polri yang bersumber dari landasan yang masih relevan namun masih perlu diorintasikan dengan perkembangan masyarakat. Tugas Kepolisian untuk memelihara keamanan dan ketertiban masyarakat, menegakan hukum dan memberikan perlindungan, pengayoman, dan pelayanan kepada masyarakat untuk mewujudkan keinginan keinginan dalam hukum agar menjadi kewajiban dan ditaati oleh masyarakat.

Kata Kunci : Tugas dan Fungsi Kepolisian, Penegak Hukum, 


\section{PENDAHULUAN}

Tugas pokok dan fungsi Polri, selain sebagai pengayom masyarakat juga sebagai penegak hukum. Fungsi tersebut merupakan sebagian dari implementasi Pasal 1 ayat (5) UU Nomor 2 Tahun 2002 tentang Kepolisian Negara Republik Indonesia menetapkan bahwa :

"Keamanan dan ketertiban masyarakat adalah suatu kondisi dinamis masyarakat sebagai salah satu prasyarat terselenggaranya proses pembangunan nasional yang ditandai oleh terjaminnya tertib dan tegaknya hukum serta terbinanya ketentraman yang mengandung kemampuan membina serta mengembangkan potensi dan kekuatan masyarakat dalam menangkal, mencegah, dan menanggulangi segala bentuk pelanggaran hukum dan bentukbentuk gangguan lainnya dapat meresahkan masyarakat"

Kepolisian merupakan salah satu lembaga pemerintahan yang memegang peranan penting dalam negara, terutama bagi negara yang berdasar atas hukum (Pasal 1 ayat (3) UUD 1945). Di dalam negara hukum, kehidupan hukum sangat ditentukan oleh faktor struktur atau lembaga hukum, disamping faktor-faktor lain, seperti substansi hukum dan faktor kultur hukum. Kepolisian Negara Republik Indonesia memiliki keterbatasan, baik dalam hal ketersedian personil, peralatan dan anggaran operasional, oleh karena itu diperlukan keterlibatan masyarakat itu sendiri dalam penciptaan keamanan dan ketertiban umum. Berkaca pada tugas dan peranan negara dalam melindungi seluruh warga negaranya, maka dalam terminologi ilmu pemerintahan negara dimanapun di dunia ini, yakni : memberikan layanan civil (Civil Service), memberikan layanan publik (Public Service) dan memberikan penguatan pemberdayaan masyarakat (Empowering) melalui kebijakankebijakannya.Tiap-tiap warga Negara bersamaan kedudukannya di dalam hukum dan pemerintahan, wajib menjunjung hukum dan pemerintahan itu dengan tidak ada kecualinya (Pasal 27 ayat (1) Undang-Undang Dasar Negara Kesatuan Republik Indonesia (UUD NKRI Tahun 1945). Pelaksanaan prinsip etika politik dan hukum dari tugas Negara untuk melindungi seluruh rakyatnya itu, diselenggarakan melalui salah satu tugas pemerintahan di bidang kepolisian negara. Hal ini ditegaskan dalam Pasal 30 ayat (4) UUD NKRI Tahun 1945 serta disebutkan dalam Pasal 2 Undangundang No. 2 Tahun 2002. Sejak lama masyarakat menghendaki Kepolisian Negara Republik Indonesia (Polri) dalam menjalankan tugasnya tidak bersifat militeristik yakni menggunakan senjata melawan musuh masyarakat, tetapi yang diinginkan masyarakat adalah Polri bisa lebih berperan sebagai sosok hukum yang hidup yang bertugas melindungi, mengayomi dan melayani masyarakat serta bertindak berdasarkan hukum yang berlaku. 
Sejalan dengan hal tersebut, Soerjono Soekanto ${ }^{1}$ berpendapat bahwa: "hukum dan penegak hukum merupakan sebagian faktor penegakan hukum yang tidak bisa diabaikan, jika diabaikan akan menyebabkan tidak tercapainya penegakan hukum yang diharapkan". Penegakan hukum, penjagaan keamanan dan ketertiban masyarakat (Kamtibmas) ${ }^{2}$ serta pelayanan dan pengayoman masyarakat adalah tugas pokok polisi sebagai profesi mulia, yang aplikasinya harus berdasarkan undang-undang yang berlaku dan hak azasi manusia. Atau dengan kata lain harus bertindak secara professional dan memegang kode etik secara ketat dan keras, sehingga tidak terjerumus kedalam prilaku yang dibenci masyarakat.

Masyarakat dan polisi merupakan dua kegiatan yang tidak bisa di pisahkan. Tanpa masyarakat, tidak akan ada polisi dan tanpa polisi, proses-proses dalam masyarakat tidak akan berjalan dengan lancar dan produktif. Kenyataan tersebut di atas, menurut Barda Nawawi Arief $^{3}$, bahwa Polri dalam menjalankan tugasnya berperan ganda baik sebagai penegak hukum maupun sebagai pekerja sosial (sosial worker) pada aspek sosial dan kemasyarakatan (pelayanan dan pengabdian). Prilaku masyarakat dan penegak hukum menurut Soerjono Soekanto ${ }^{4}$ berpendapat bahwa :

Salah satu fungsi hukum baik sebagai kaidah maupun sebagai sikap tindak atau perilaku teratur adalah membimbing perilaku manusia. Masalah pengaruh hukum tidak hanya terbatas pada timbulnya ketaatan atau kepatuhan pada hukum, tapi mencakup efek total dari hukum terhadap sikap tindak atau prilaku baik yang bersifat positif maupun negatif. Pembaharuan Undang-undang Kepolisian Indonesia, Undang-undang Nomor 2 Tahun 2002 dimaksudkan untuk lebih memantapkan kedudukan dan peran Polri sebagai fungsi pemerintahan meliputi pemeliharaan keamanan dan ketertiban masyarakat, penegakan hukum, perlindungan dan pengayoman dan pelayanan kepada masyarakat yang menjunjung tinggi hak asasi manusia ${ }^{5}$, harus bebas dari pengaruh kekuasaan pihak manapun, yakni yang

${ }^{1}$ Soerjono Soekanto, Faktor-faktor yang Mempengaruhi Penegakan Hukum, Cet Kelima, Rajawali, Jakarta, 2004, hlm, 5.

${ }^{2}$ Keamanan dan ketertiban masyarakat adalah suatu kondisi dinamis masyarakat sebagai salah satu prasyarat terselenggaranya proses pembangunan nasional dalam rangka tercapainya tujuan nasional yang ditandai oleh terjaminnya keamanan, ketertiban, dan tegaknya hukum, serta terbinanya ketenteraman, yang mengandung kemampuan membina serta mengembangkan potensi dan kekuatan masyarakat dalam menangkal, mencegah, dan menanggulangi segala bentuk pelanggaran hukum dan bentuk-bentuk gangguan lainnya yang dapat meresahkan masyarakat, Pasal 1 angka (5) Undang-undang Nomor 2 Tahun 2002 tentang Kepolisian Negara Republik Indonesia.

${ }^{3}$ Barda Nawawi, Bunga Rampai Kebijakan Hukum Pidana, PT. Citra Aditya Bakti, Bandung, 2005, hlm., 5 .

${ }^{4}$ Soerjono Soekanto, Efektivitas Hukum Dan Peranan Sanksi, Remaja Karya, Bandung, 2005, hlm., 10.

${ }^{5}$ Pasal 4 Undang-undang Nomor 2 Tahun 2002 Tentang Kepolisian. 
dilaksanakan secara merdeka terlepas dari pengaruh kekuasaan pemerintah dan pengaruh kekuasaan lainnya.

Berdasarkan latar belakang di atas, yang terpenting adalah bagaimana Polri dalam melaksanakan peran dan fungsinya dengan baik sehingga dapat diterima oleh masyarakat sehingga dapat menjaga keamanan dan ketertiban dengan memperoleh dukungan maksimal dari masyarakat.

\section{RUMUSAN MASALAH}

Adapun rumusan masalah sebagai berikut :

1. Bagaimanakah tugas dan fungsi Kepolisian dalam perannya sebagai penegak hukum menurut Undang-Undang No. 2 Tahun 2002 tentang Polri?

2. Faktor-faktor apakah yang menghambat peran dan fungsi kepolisian dalam melaksanakan tugasnya?

\section{METODE PENELITIAN}

Sebuah karya ilmiah terutama karya ilmiah penelitian hukum diharuskan menggunakan metode penelitian hukum. Ilmu hukum berusaha untuk menampilkan hukum secara integral sesuai dengan kebutuhan kajian ilmu hukum itu sendiri, sehingga metode penelitian dibutuhkan untuk memperoleh arah penelitian yang komprehensif. ${ }^{6}$ Sebenarnya ilmu hukum mempunyai ciri-ciri sebagai ilmu yang bersifat preskriptif dan terapan. Dalam preskriptif, ilmu hukum mempelajari tujuan hukum, nilai-nilai keadilan dalam suatu hukum, baik buruk suatu aturan hukum, konsep-konsep dan norma hukum. sedangkan dalam ilmu terapan, ilmu hukum menetapkan suatu prosedur, ketentuan-ketentuan dan batasan-batasan dalam menegakan suatu aturan hukum. ${ }^{7}$

Penelitian hukum ini adalah penelitian hukum normatif (legal research) biasanya "hanya" merupakan studi dokumen, yakni menggunakan sumber- sumber data sekunder saja yang berupa peraturan perundang-undangan, keputusan peradilan, teori hukum dan pendapat para sarjana. Itu pula sebabnya digunakan analisis secara kualitatif karena datanya bersifat kualitatif. Dalam penelitian hukum normatif akan mengkaji norma-norma hukum positif yang berupa peraturan perundang-undangan yang berkaitan dengan Tugas dan Fungsi Kepolisian dalam Perannya Sebagai Penegak Hukum Menurut Undang-undang Nomor 2 Tahun 2002 Tentang Kepolisian.

\footnotetext{
${ }^{6}$ Yati Nurhayati, "Perdebatan Metode Normatif dengan Metode Empirik Dalam Penelitian Ilmu Hukum Ditinjau Dari Karakter, Fungsi dan Tujuan Ilmu Hukum”, Jurnal Al Adl, Volume 5 Nomor 10, 2013, hlm. 15.

${ }^{7}$ Yati Nurhayati, Pengantar Ilmu Hukum, Nusa Media, Bandung, 2020, hlm. 9.
} 


\section{PEMBAHASAN}

\section{POLRI dan Penegakan Hukum}

Polisi adalah suatu pranata umum sipil yang mengatur tata tertib (orde) dan hukum.Kadangkala pranata ini bersifat militaristis, seperti di Indonesia sebelum Polri dilepas dari ABRI. Polisi dalam lingkungan pengadilan bertugas sebagai penyidik. Menurut Soebroto Brotodiredjo $^{8}$, istilah polisi berasal dari istilah Yunani Kuno "politeia" yang berarti pemerintahan suatu polis atau kota. W.J.S. Poerwadarminta, ${ }^{9}$ memberikan arti pada kata polisi sebagai badan pemerintahan yang bertugas memelihara keamanan dan ketertiban umum seperti menangkap orang yang melanggar undang-undang atau pegawai negara yang bertugas menjaga keamanan.

Menurut Pasal 5 ayat (1) UU No. 2 Tahun 2002 : “Kepolisian Negara Republik Indonesia merupakan alat negara yang berperan dalam memelihara keamanan dan ketertiban masyarakat, menegakkan hukum, serta memberikan perlingdungan, pengayoman, dan pelayanan kepada masyarakat dalam rangka terpeliharanya keamanan dalam negeri”.

Sedangkan Penegakan hukum merupakan suatu proses untuk mewujudkan keinginankeinginan dalam hukum agar menjadi kewajiban dan ditaati oleh masyarakat ${ }^{10}$. Secara konseptual menurut Soerjono Soekanto ${ }^{11}$,

"penegakan hukum terletak pada kegiatan menyerasikan hubungan nilainilai yang dijabarkan di dalam kaedahkaedah yang mantap dan mengejawantah serta sikap tindak sebagai rangkaian penjabaran nilai akhir dan untuk menciptakan, memelihara dan mempertahankan pergaulan hidup. Penegakan hukum tidak bisa terlepas dari hak asasi manusia, namun dengan adanya alat-alat paksa khusus (bijzonder dwangmiddelen) yang dimaksud alat paksa disini bukan merupakan pemaksaan fisik melainkan alat pemaksa yang sah diatur oleh ketentuan perundangundangan seperti penangkapan, penahanan dan penyitaan".

Kepolisian Negara Republik Indonesia (POLRI) adalah Kepolisian Nasional di Indonesia yang bertanggungjawab langsung di bawah Presiden.Polri mengemban tugas-tugas kepolisian di seluruh wilayah Indonesia yaitu memelihara keamanan dan ketertiban masyarakat, menegakan hukum dan memberikan perlindungan, pengayoman dan pelayanan kepada masyarakat. Polri sebagai agen penegak hukum dan pembina keamanan dan ketertiban

\footnotetext{
${ }^{8}$ Soebroto Brotodirejo, Polri Sebagai Penegak Hukum, Sespimpol. Bandung, 1989, hlm, 2.

${ }^{9}$ W.J.S.Poerwadarminta, Kamus Umum Bahasa Indonesia, PN Balai Pustaka, Jakarta, 1985, hlm.,763.

${ }^{10}$ Baringbing Simpul, RE, Mewujudkan Supremasi Hukum, Pusat Kegiatan Reformasi, Jakarta, 2001, hlm. 55.

${ }^{11}$ Seorjono Soekanto, Hukum Acara Pidana, Badan Penerbit Universitas Diponegoro, Semarang, 2006, hlm, 7 .
} 
masyarakat. Konsepsi tugas, fungsi dan peran Polri yang bersumber dari landasan yang masih relevan namun masih perlu diorintasikan dengan perkembangan masyarakat.

Polri dengan keberadaannya membawa empat peran strategis, yakni:

1. Perlindungan masyarakat;

2. Penegakan Hukum;

3. Pencegahan pelanggaran hukum;

4. Pembinaan Keamanan dan Ketertiban masyarakat.

Sebagaimana diatur dalam ketentuan UU No. 2 Tahun 2002 tentang Polri secara gamblang dirumuskan bahwa tugas pokok Polri adalah penegak hukum, pelindung, pengayom dan pembimbing masayarakat terutama dalam rangka kepatuhan dan ketaatan pada hukum yang berlaku. Dalam ketentuan Undang-undang tersebut, ada dua hal yang mendasar tugas utama Polri sebagaimana yang termuat dalam Tribrata maupun Catur Prasetya Polri. Sebagaimana diatur dalam UU No. 2 Tahun 2002, khususnya pada Pasal 13. Dalam ketentuan Pasal 13 ditegaskan bahwa Polri bertugas:

a. memelihara keamanan dan ketertiban masyarakat;

b. menegakkan hukum; dan

c. memberikan perlindungan, pengayoman dan pelayanan kepada masyarakat ${ }^{12}$. Oleh Satjipto Rahardjo ${ }^{13}$ sebagai penegakan hukum (Law Enforceman Officer) dan pemulihan ketertiban (Order maintenance).

\section{Tugas dan Fungsi Kepolisian dan Kendala dalam Penegakan Hukum}

a. Tugas dan Fungsi Kepolisian Sebagai Penegak Hukum Menurut UU Nomor 2 Tahun 2002 tentang Kepolisian Negara Republik Indonesia.

Istilah Penegak Hukum (law enforcement officer) yang dalam arti sempit hanya berarti Polisi tetapi dapat juga mencakup Jaksa. Akan tetapi di Indonesia biasanya diperluas pula dengan para Hakim dan ada kecenderungan kuat memasukkan pula dalam pengertian penegak hukum ini adalah Pengacara (advokat). Dalam pengertian luas terakhir ini, dapat dipergunakan terjemahan dari rechthandhaving, yang artinya penegakkan hukum. Secara konsepsional, maka inti dan arti penegakkan hukum terletak

\footnotetext{
${ }^{12}$ Pasal 13, UU No. 2 Tahun 2002

13 Satjipto Rahardjo, Penyelenggaraan Keadilan Dalam Masyarakat Yang Sedang Berubah, MasalahMasalah Hukum, Nomor 1-6 Tahun X/10 hlm. 20.
} 
pada kegiatan menyerasikan nilai-nilai yang terjabarkan di dalam kaidah-kaidah yang mantap dan mengejawantah dan sikap tindak sebagai rangkaian penjabaran nilai tahap akhir, untuk menciptakan, memelihara dan mempertahankan kedamaian pergaulan hidup. Peranan Polri menurut Pasal 1 ayat (5) UU No. 2 Tahun 2002 tentang Kepolisian Negara Republik Indonesia yaitu:

"Keamanan dan ketertiban masyarakat adalah suatu kondisi dinamis masyarakat sebagai salah satu prasyarat terselenggaranya proses pembangunan nasional yang ditandai oleh terjaminnya tertib dan tegaknya hukum serta terbinanya ketentraman yang mengandung kemampuan membina serta mengembangkan potensi dan kekuatan masyarakat dalam menangkal, mencegah, dan menanggulangi segala bentuk pelanggaran hukum dan bentuk-bentuk gangguan lainnya dapat meresahkan masyarakat".

Peranan Polri menurut Pasal 1 ayat (5) UU No. 2 Tahun 2002 tentang Kepolisian Negara Republik Indonesia yaitu: Peranan Polri yang diuraikan di atas adalah sejalan dengan fungsi Kepolisian yang ditetapkan dalam UU No. 2 Tahun 2002 tentang Kepolisian sebagai berikut:

1. Pasal 2 UU No. 2 Tahun 2002 fungsi Kepolisian adalah : "salah satu fungsi pemerintahan negara di bidang pemeliharaan kemanan dan ketertiban masyarakat, penegak hukum, perlindungan, pengayoman, dan pelayanan kepada masyarakat".

2. Pasal 5 ayat (1) UU No. 2 Tahun 2002. "Kepolisian Negara Republik Indonesia merupakan alat negara yang berperan dalam memelihara keamanan dan ketertiban masyarakat, menegakkan hukum, serta memberikan perlingdungan, pengayoman, dan pelayanan kepada masyarakat dalam rangka terpeliharanya keamanan dalam negeri"

3. Dalam rangka melaksanakan ketentuanketentuan dalam Pasal 5 UU No. 2 Tahun 2002, maka sesuai dengan Pasal 13 UU No. 2 Tahun 2002, Kepolisian Negara mempunyai tugas pokok:

a. memelihara keamanan dan ketertiban masyarakat;

b. Menegakkan hukum; dan

c. Memberikan perlindungan, pengayoman, dan pelayanan kepada masyarakat.

4. Pasal 14 UU No. 2 Tahun 2002, mengatur mengenai pelaksanaan tugas pokok sesuai yang dimaksud Pasal 13 UU No. 2 Tahun 2002, bertugas:

a. melaksanakan pengaturan, penjagaan, pengawalan, dan patroli terhadap kegiatan masyarakat dan pemerintah sesuai kebutuhan;

b. menyelenggarakan segala kegiatan dalam rangka menjamin keamanan, ketertiban, dan kelancaran lalu lintas di jalan;

c. membina masyarakat untuk meningkatkan partisipasi masyarakat, kesadaran hukum masyarakat serta ketaatan warga masyarakat terhadap hukum dan peraturan perundangundangan;

d. turut serta dalam pembinaan hukum nasional; 
e. memelihara ketertiban dan menjamin keamanan umum; melakukan koordinasi, pengawasan, dan pembinaan teknis terhadap kepolisian khusus, penyidik pengawai negeri sipil, dan bentuk-bentuk pengawasan swakarsa

f. melakukan penyelidikan dan penyidikan terhadap semua tindak pidana sesuai dengan hukum acara pidana dan perundang-undangan lainnya.

Kenyataan tersebut di atas, menurut Barda Nawawi Arief ${ }^{14}$, bahwa Polri dalam menjalankan tugasnya berperan ganda baik sebagai penegak hukum (dibidang peradilan pidana) maupun sebagai pekerja sosial (sosial worker) pada aspek sosial dan kemasyarakatan (pelayanan dan pengabdian). Selanjutnya, secara universal fungsi lembaga kepolisian mencakup dua hal yaitu pemeliharaan keamanan dan ketertiban (peace \& order maintenance) dalam penegakan hukum (law enforcement).

b. Faktor Penghambat Kepolisian dalam Melaksanakan Tugasnya

Dalam rangka penegakan hukum Polri sangat dipengaruhi oleh faktor-faktor Penghambat Dalam Pelaksanaan fungsinya yang saling berkaitan dengan beberapa situasi dan kondisi masyarakat setempat. Dalam praktik penegakan hukum, pihak Kepolisian menghadapi berbagai kendala, baik yang bersifat operasional maupun prosedural legal dan kemudian kendala ini tidak memberikan hasil yang optimal dalam upaya menekan kenaikan angka kriminalitas, bahkan terjadi sebaliknya. Semua hambatan-hambatan tersebut di atas bermuara pada modelmodel pendekatan yang dipergunakan yang harus didukung dengan profesionalisme, mental, pendidikan bagi setiap anggota Polri. Berkenaan dengan hal tersebut, untuk mengetahui hambatan-hambatan terhadap peran dan fungsi yang dilakukan oleh kepolisian pada umumnya dan Polmas pada khususnya, dengan mempergunakan faktorfaktor umum yang mempengaruhi proses penegakan hukum $^{15}$ ialah:

1. Faktor hukumnya sendiri;

2. Faktor penegak hukum, yaitu pihakpihak yang membentuk maupun

3. menerapkan hukum;

4. Faktor sarana atau fasilitas;

5. Faktor masyarakat, yaitu lingkungan dimana hukum terasebut berlaku atau diterapkan;

6. Faktor kebudayaan, yaitu sebagai hasil karya, cipta dan rasa yang didasarkan pada karsa manusia dalam pergaulan hidup.

c. Peran Polisi dalam Peradilan Pidana

\footnotetext{
${ }^{14}$ Barda Nawawi Arief, Kebijakan Kriminal, Bahan Seminar, 2005, hlm., 5.

${ }^{15}$ Soerjono Soekanto, Faktor-faktor yang Mempengaruhi Penegakan Hukum, hlm.,8.
} 
Tugas dan peran Polisi memberikan informasi dan Tugas dan wewenang Kepolisian meliputi :

"Pemeliharaan keamanan dan ketertiban masyarakat, penegakan hukum, dan memberikan perlindungan, pengayoman dan pelayanan kepada masyarakat Tugastugas kepolisian dimaksud secara umum diatur dalam Pasal 14 ayat (1) huruf a sampai dengan 1 UU No. 2 Tahun 2002, sedangkan untuk kewenangan secara umum diatur dalam Pasal 15 ayat (1) UU No. 2 Tahun 2002, kewenangan yang berdasarkan pada peraturan perundang-undangan lain dirumuskan dalam Pasal 15 ayat (2) UU No. 2 Tahun 2002. Kewenangan secara khusus dalam menyelenggarakan tugas bidang proses pidana selain diatur dalam Pasal 16 Undang-undang No. 2 Tahun 2002, juga diatur dalam Pasal 7 ayat (1) Undangundang No. 8 Tahun 1981 tentang KUHAP. ${ }^{16}$

Peran polisi dalam penyelidikan menurut Kitab Undang-undang Hukum Acara Pidana Pengertian Penyelidikan adalah serangkaian tindakan penyelidik untuk mencari dan menemukan suatu peristiwa yang diduga sebagai tindak pidana guna menentukan dapat atau tidaknya dilakukan penyidikan menurut cara yang diatur dalam Undangundang ini. Penyelidikan merupakan salah satu cara atau metode atau sub daripada fungsi penyidikan yang mendahului tindakan lain, yaitu penindakan berupa penangkapan, penahanan, penggeledahan, penyitaan, pemeriksaan surat, pemanggilan, tindakan pemeriksaan, dan penyerahan berkas kepada penuntut umum.

Dalam tahap penangkapan, berdasarkan Kitab Undang-undang Hukum Acara Pidana Pengertian Penangkapan adalah suatu tindakan penyidik berupa pengekangan sementara waktu kebebasan tersangka atau terdakwa apabila terdapat cukup bukti guna kepentingan penyidikan atau penuntutan dan atau peradilan dalam hal serta menurut cara yang diatur dalam undang-undang. Pelaksanaan tugas penangkapan dilakukan oleh Kepolisian penangkapan serta uraian singkat perkara kejahatan yang dipersangkakan serta tempat ia diperiksa hakim dengan penetapannya, dalam hal serta menurut cara yang diatur dalam undang-undang penuntut umum atau Penyidikan.

Dalam tahap penahanan, Berdasarkan Kitab Undangundang Hukum Acara Pidana UU No. 8 Tahun 1981 Pengertian Penyidikan adalah serangkaian tindakan penyidik dalam hal dan menurut cara yang diatur dalam undangundang ini untuk mencari serta mengumpulkan bukti yang dengan bukti itu membuat terang tentang tindak pidana yang terjadi dan guna menemukan tersangkanya.

${ }^{16}$ Sadjijono, Fungsi Kepolisian dalam pelaksanaan Good Governance, Laksbang, Yogyakarta, 2005, hlm.103-105. 


\section{PENUTUP}

\section{A. Kesimpulan}

Berdasarkan hasil pembahasan penulis terhadap perbandingan sistem hukum mengenai disiplin hukum, maka dapat diambil kesimpulan :

1. Tugas dan Fungsi Kepolisian Sebagai Penegak Hukum Menurut UU Nomor 2 Tahun 2002 tentang Kepolisian Negara Republik Indonesia dapat dilihat pada Pasal 2 UU No. 2 Tahun 2002 mengenai fungsi Kepolisian. Fungsi kepolisian adalah "salah satu fungsi pemerintahan negara di bidang pemeliharaan kemanan dan ketertiban masyarakat, penegak hukum, perlindungan, pengayoman, dan pelayanan kepada masyarakat".

2. Faktor penghambat kepolisian dalam melaksanakan tugasnya dalam penegakan hukum yaitu :

a. Faktor hukumnya sendiri;

b. Faktor penegak hukum, yaitu pihak-pihak yang membentuk maupun menerapkan hukum;

c. Faktor sarana atau fasilitas;

d. Faktor masyarakat, yaitu lingkungan dimana hukum terasebut berlaku atau diterapkan;

e. Faktor kebudayaan, yaitu sebagai hasil karya, cipta dan rasa yang didasarkan pada karsa manusia dalam pergaulan hidup.

\section{B. Saran}

Sebaiknya masyarakat turut membantu tugas Kepolisian sehingga terjalin hubungan yang baik antara masyarakat dan Polri dan sehingga terhindar dari benturan yang dapat merugikan masyarakat dan citra Polri sendiri. Serta sebaiknya polri sebagai penegak hukum dalam melaksanakan tugas dan wewenangnya tidak melakukan pilih kasih dalam menindaki pelaku tindak pidana.

\section{Buku}

\section{DAFTAR PUSTAKA}

Barda Nawawi, 2005, Bunga Rampai Kebijakan Hukum Pidana, PT. Citra Aditya Bakti, Bandung.

Baringbing Simpul, RE, 2001, Mewujudkan Supremasi Hukum, Pusat Kegiatan Reformasi, Jakarta. 
Soerjono Soekanto, 2004, Faktor-faktor yang Mempengaruhi Penegakan Hukum, Cet Kelima, Rajawali, Jakarta.

Soerjono Soekanto, 2005, Efektivitas Hukum Dan Peranan Sanksi, Remaja Karya, Bandung.

Soebroto Brotodirejo, 1989, Polri Sebagai Penegak Hukum, Sespimpol. Bandung

Satjipto Rahardjo, Penyelenggaraan Keadilan Dalam Masyarakat Yang Sedang Berubah, Masalah-Masalah Hukum, Nomor 1-6 Tahun X/10.

Seorjono Soekanto, 2006, Hukum Acara Pidana, Badan Penerbit Universitas Diponegoro, Semarang.

Soerjono Soekanto, 2008, Faktor-faktor yang Mempengaruhi Penegakan Hukum, Bandung

Sadjijono, 2005, Fungsi Kepolisian dalam pelaksanaan Good Governance, Laksbang, Yogyakarta.

W.J.S.Poerwadarminta,1985, Kamus Umum Bahasa Indonesia, PN Balai Pustaka, Jakarta.

Yati Nurhayati, 2020, Pengantar Ilmu Hukum, Nusa Media, Bandung.

\section{Peraturan Perundang-Undangan}

Undang-undang Nomor 2 Tahun 2002 tentang Kepolisian Negara Republik Indonesia.

\section{Jurnal}

Yati Nurhayati, "Perdebatan Metode Normatif dengan Metode Empirik Dalam Penelitian Ilmu Hukum Ditinjau Dari Karakter, Fungsi dan Tujuan Ilmu Hukum", Jurnal Al Adl, Volume 5 Nomor. 10, 2013. 